\title{
Serotype- and virulence-associated gene profile of Streptococcus suis isolates from pig carcasses in Chiang Mai Province, Northern Thailand
}

\author{
Kanruethai WONGSAWAN ${ }^{1) *}$, Marcelo GOTTSCHALK ${ }^{2)}$ and Prasit THARAVICHITKUL ${ }^{3)}$ \\ ${ }^{1)}$ Department of Veterinary Biosciences and Public Health, Faculty of Veterinary Medicine, Chiang Mai University, Chiang Mai 50100, \\ Thailand \\ 2) Department of Pathology and Microbiology, Faculty of Veterinary Medicine, University of Montréal, St-Hyacinthe, Québec, J2S 2M2, \\ Canada \\ 3) Department of Microbiology, Faculty of Medicine, Chiang Mai University, Chiang Mai 50200, Thailand
}

(Received 23 July 2014/Accepted 30 September 2014/Published online in J-STAGE 3 November 2014)

ABSTRACT. In this present study, the serotype of 40 Streptococcus suis isolates from submaxillary glands of pig carcasses sold in wet markets in Chiang Mai Province, northern Thailand, was investigated. Eleven serotypes, including types 2, 3, 4, 5, 7, 8, 9, 17, 21, 22 and 31, were found in the isolates by a Multiplex PCR combined with serum agglutination. Of the eleven serotypes present, type 3 was the most prevalent, while types $2,4,5$ and 21 were of primary interest due to their human isolate serotype. The $m r p+/ e p f-/ s l y$ - genotype was found to be the most prevalent genotype. This study indicates the importance of effective control of human S. suis infection due to raw pork or pig carcass handling in northern Thailand.

KEY WORDS: pig carcass, raw pork, serotype, Streptococcus suis, virulence-associated gene profile

doi: 10.1292/jvms.14-0380; J. Vet. Med. Sci. 77(2): 233-236, 2015

Streptococcus suis is one of the most extensively emerging worldwide swine pathogens, in addition to being a zoonotic agent for people who come in close contact with pigs or pork-derived products [4]. Presently, 35 serotypes of $S$. suis have been described. Infection is still frequently found in people from the northern region of Thailand. Almost all cases have a background history of consumption of raw pork, raw pig blood or internal organs of pigs [11-13, 21, 25]. This traditional consumption behavior is considered to be a major risk factor in this region. $S$. suis is a genetically diverse agent, and the difference in virulence among the $S$. suis strains has been previously determined. Although the presence of three virulence-associated factors, suilysin (SLY, encoded by gene sly), a hemolysin which has a cytotoxic effect and two proteins of unknown function, the muramidase-released protein (MRP, encoded by gene $m r p$ ) and the secreted extracellular factor (EF, encoded by gene epf) [20], cannot categorically predict the virulence of an $S$. suis serotype 2 strain [3], genes encoding these virulenceassociated factors have been widely used to genetically characterize $S$. suis strains. Due to limited access to costly $S$. suis antisera in Thailand, in the past, many $S$. suis isolates from pigs were considered untypable strains when tested with the few serotype-specific PCR tests available. This led to a

\footnotetext{
*Correspondence to: Wongsawan, K., Department of Veterinary Biosciences and Public Health, Faculty of Veterinary Medicine, Chiang Mai University, Chiang Mai 50100, Thailand.

e-mail: KanreuthaiW@gmail.com

(C)2015 The Japanese Society of Veterinary Science

This is an open-access article distributed under the terms of the Creative Commons Attribution Non-Commercial No Derivatives (by-nc-nd) License $<$ http://creativecommons.org/licenses/by-nc-nd/3.0/> .
}

loss of authentic data regarding the serotype of pig isolates. Thus, the objective of this study was to serotype untypable $S$. suis strains isolated from the submaxillary glands of pig carcasses sold in retail wet markets in Chiang Mai Province, Northern Thailand, by serotyping based on PCR detection of serotype-specific genes and using serotype-specific antibodies. Additionally, to genetically characterize S. suis strains, the presence of three virulence-associated genes encoding MRP, EF and SLY was also investigated.

A total of 40 S. suis isolates collected in the 2001-2002 period were included in this study. All of them were isolated from the submaxillary glands of pig carcasses purchased from six wet markets in Chiang Mai Province, northern Thailand, and kept in bacterial storage medium at $-80^{\circ} \mathrm{C}$. The bacterial isolates were recovered from bacterial stock cultures by subculture on Columbia blood agar (Oxoid, Hampshire, U.K.) containing $5 \%(\mathrm{v} / \mathrm{v})$ defibrinated sheep blood and incubated at $37^{\circ} \mathrm{C}$ in $5 \% \mathrm{CO}_{2}$ for $24 \mathrm{hr}$. The colonies were confirmed as $S$. suis by both the API 20 Strep kit (BioMerieux, Marcy l'Etoile, France) and the $g d h$-specific PCR amplification product [18]. Serotyping was performed first using PCR detection of capsular (cps) biosynthesis genes for serotypes $1,14,2,1 / 2,9$ and 16 [20,23], which represent those that are mostly isolated from pigs and human cases (types 2, 14, 16) in Southeast Asia, Europe and Canada [6, 15, 19, 21, 24, 26, $27,29]$. Five pairs of cps-specific primers and $g d h$-specific primers were used, as illustrated in Table 1. The $50 \mu l$ PCR mixture contained $1 \mu \mathrm{g}$ of DNA template, $25 \mu \mathrm{l}$ of Red Dye PCR Master Mix (Merck, Mumbai, India) and $0.1 \mu \mathrm{M}$ of each primer. S. suis strain P1/7 was used as the positive control of $g d h$ and cps 2J genes, while streptococcal isolates (Streptococcus pneumoniae, Streptococcus bovis and Streptococcus agalactiae) were used as negative controls. PCR amplification was carried out in a thermal cycler under the 
Table 1. Oligonucleotide primer sequences used in this study

\begin{tabular}{|c|c|c|c|}
\hline Gene & Primer sequence $\left(5^{\prime}-3^{\prime}\right)$ & PCR product size (bp) & References \\
\hline$g d h$ & $\begin{array}{l}\text { AAGTTCCTCGGTTTTGAGCA, } \\
\text { GCAGCGTATTCTGTCAAACG }\end{array}$ & 566 & 18 \\
\hline cps $1 \mathrm{~J}$ & $\begin{array}{l}\text { TGGCTCTGTAGATCATTCTGCT, } \\
\text { TGATACGTCAAAATCCTCACCA }\end{array}$ & 637 & 20 \\
\hline cps $2 \mathrm{~J}$ & $\begin{array}{l}\text { TTTCTCGGGAGGGTTACTTC, } \\
\text { TTTGGAAGCGATTCATCTCC }\end{array}$ & 498 & 20 \\
\hline cps $9 \mathrm{H}$ & $\begin{array}{l}\text { GGGATGATTGCTCGACAGAT, } \\
\text { CCGAAGTATCTGGGCTACTGA }\end{array}$ & 303 & 20 \\
\hline cps $16 \mathrm{G}$ & $\begin{array}{l}\text { ATGATTTTTGTAACTGTAGG, } \\
\text { CCAGCTTTTCTATTTCTTTC }\end{array}$ & 487 & 23 \\
\hline$m r p$ & $\begin{array}{l}\text { CGGAGAGGAACTGATACGA, } \\
\text { CAGCTGCAGCCAAGAGCTGACTTAGGA }\end{array}$ & 515 & [GenBank: A24025] \\
\hline$m r p$ variant $\left(m r p^{*}\right)$ & $\begin{array}{l}\text { GACAGATGGTGAGGAAAATGG, } \\
\text { TGAGCTTTACCTGAAGCGGT }\end{array}$ & 1148 & 20 \\
\hline epf variant (epf*) & $\begin{array}{l}\text { GCTACGACGGCCTCAGAAATC, } \\
\text { TGGATCAACCACTGGTGTTAC }\end{array}$ & $\begin{array}{l}626 \text { for } e p f \text { and } \\
1278-2993 \text { for } e p f^{*}\end{array}$ & 28 \\
\hline sly & $\begin{array}{l}\text { CGGATCCTCAAAGCTTGACTTACGGGCC, } \\
\text { CAGCTGCAGCCACCATTCCCAAGCTAATCC }\end{array}$ & 1282 & 17 \\
\hline
\end{tabular}

Table 2. Serotypes and virulence-associated gene profiles of Streptococcus suis strain isolates from the submaxillary glands of pig carcasses in Chiang Mai, northern Thailand, collected in 2001-2002

\begin{tabular}{|c|c|c|c|c|c|c|}
\hline \multirow{2}{*}{ Strains } & \multirow{2}{*}{ Total of isolates $(\%)$} & \multicolumn{5}{|c|}{ Virulence-associated gene profile Total of isolates (\%) } \\
\hline & & $m r p+/ e p f-/ s l y-$ & mrp+lepf-/sly+ & $m r p+/ e p f^{*} / s l y+$ & mrp-lepf-/sly- & $m r p-/ e p f-/ s l y+$ \\
\hline Serotype 2 & $5(12.5)$ & 0 & 0 & 0 & 0 & $5(12.5)$ \\
\hline Serotype 3 & $7(17.5)$ & $6(15)$ & 0 & 0 & $1(2.5)$ & 0 \\
\hline Serotype 4 & $4(10)$ & 0 & $2(5)$ & $1(2.5)$ & $1(2.5)$ & 0 \\
\hline Serotype 5 & $2(5)$ & 0 & 0 & 0 & $2(5)$ & 0 \\
\hline Serotype 7 & $1(2.5)$ & 0 & 0 & 0 & 0 & $1(2.5)$ \\
\hline Serotype 8 & $1(2.5)$ & 0 & 0 & 0 & 0 & $1(2.5)$ \\
\hline Serotype 9 & $1(2.5)$ & 0 & 0 & 0 & $1(2.5)$ & 0 \\
\hline Serotype 17 & $1(2.5)$ & $1(2.5)$ & 0 & 0 & 0 & 0 \\
\hline Serotype 21 & $1(2.5)$ & $1(2.5)$ & 0 & 0 & 0 & 0 \\
\hline Serotype 22 & $1(2.5)$ & $1(2.5)$ & 0 & 0 & 0 & 0 \\
\hline Serotype 31 & $1(2.5)$ & 0 & 0 & 0 & $1(2.5)$ & 0 \\
\hline Untypable $^{a}$ & $15(37.5)$ & $9(22.5)$ & $2(5)$ & 0 & $2(5)$ & $2(5)$ \\
\hline Total & 40 & $18(45)$ & $4(10)$ & $1(2.5)$ & $8(20)$ & $9(22.5)$ \\
\hline
\end{tabular}

a) Isolates did not agglutinate with any of the 34 serotype antisera and were negative by serotyping using PCR.

following conditions: initial denaturation for $2 \mathrm{~min}$ at $94^{\circ} \mathrm{C}$, 35 cycles of denaturation for $1 \mathrm{~min}$ at $94^{\circ} \mathrm{C}$, annealing for 1 min at $50^{\circ} \mathrm{C}$ and extension for $1.30 \mathrm{~min}$ at $72^{\circ} \mathrm{C}$, followed by final extension for $10 \mathrm{~min}$ at $72^{\circ} \mathrm{C}$. Amplified PCR products of $c p s$-positive strains were sequenced and compared with the GenBank database using the BLAST software maintained by the National Center for Biotechnology Information (NCBI) (http://www.ncbi.nlm.nih.gov/BLAST).

Only 6 of the $40 \mathrm{~S}$. suis isolates were successfully serotyped by PCR; five were either cps type 2 or type $1 / 2$, and one was cps type 9 . The remaining 34 isolates were PCR negative and inferred to be serotypes other than these, and they were further identified by a coagglutination test with 34 serotype-specific antibodies (serotype $1 / 2$ reacts with both serotypes 1 and 2 specific-antibodies) at the Reference Labo- ratory for $S$. suis serotyping, Faculty of Veterinary Medicine, University of Montreal, Canada. Since PCR cannot differentiate serotype 2 from serotype 1/2, the five cps 2 or cps $1 / 2$ PCR-positive isolates were also tested with specific antibodies. Thus, a total of 39 isolates were further identified by a coagglutination test with serotype-specific antibodies. The 35 serotypes of $S$. suis reference strains and the reference strains of other bacterial species were used as positive and negative controls, respectively. The results confirmed that all five serotype 2 or $1 / 2$ PCR-positive isolates were, in fact, serotype 2 . Six serotypes were found from 34 PCR-negative isolates, namely, serotypes $3,4,5,7,8$ and 31 . Collectively, of the 40 isolates tested, eight serotypes of $S$. suis were found (Table 2). Eighteen isolates (45\%) did not agglutinate with any of the 34 serotype antisera. The presence of non-typable 
strains in our study is consistent with findings of Kerdsin et al. [10] and Maneerat et al. [14], who showed that half of the isolates recovered from asymptomatic pigs were untypable. In order to complete the serotyping, these untypable strains were tested with a recently described two-step multiplex PCR assay for the serotyping of all S. suis serotypes [16]. The serotypes of only three of the untypable strains by coagglutination where positively serotyped by PCR, and they included serotypes 17, 21 and 22 (Table 2). These strains are probably not encapsulated. The remaining untypable strains may correspond to already described serotypes with some mutations in the cps genes that prevent the PCR test from correctly identifying them. They may also belong to either unencapsulated or true encapsulated strains that belong to novel, not-yet described serotypes [6].

Most typable strains were serotypes other than serotype 2, with serotype 3 being the most prevalent ( 7 of 25), suggesting a wide spread of $S$. suis in certain sites of pig carcasses, including the head/neck region, from which the submaxillary gland was taken. This agrees with findings from Hong Kong, where an $S$. suis serotype other than serotype 2 was found in the head/neck region, bones and tails of pig carcasses sold in wet markets [9]. However, S. suis serotype 2 , the most common cause of human infection in Thailand, was also found among typable strains from the submaxillary glands of pig carcasses in our study ( 5 of 25). This finding strongly suggests that handling and consumption of raw pork represent major risks for transmission of $S$. suis serotype 2 to humans in this region. The population-based study of Takeuchi et al. (2012) [21] supported our suggestion; the results showed that $70 \%$ of S. suis-infected patients (mostly serotype 2) in Phayao Province in Northern Thailand had recently consumed raw pork dishes. Although serotype 2 is the most prevalent type recovered from humans, zoonotic cases involving serotypes $1,4,5,14,16,21$ and 24 have also been reported $[1,5,8,12,13,15]$, with serotypes 5 and 24 being the most recently reported cases in Thailand [12]. Serotype 5 strains have also been isolated from humans in U.S.A. and Europe [7, 8]. Serotypes 4 and 5 were identified in our study, and their numbers were similar to those found for serotype 2, suggesting their long-term existence in this area and their potential to cause disease in both swine and humans. Serotypes 3, 7, 8 and 31 were also present in pig carcasses, indicating that they are probably virulent for pigs. Although they have so far not been isolated from human patients, an eventual role in zoonosis cannot be completely ruled out.

To genotype $S$. suis isolates, three virulence-associated genes, mrp, epf and sly, were amplified by multiplex PCR. The variants of $m r p\left(m r p^{*}\right)$ and epf (epf*) genes were also detected to characterize $S$. suis. The primer sequences of virulence-associated genes $[17,20,28]$ are illustrated in Table 1 . The $S$. suis strain P1/7 was used as the positive control for the presence of mrp, epf and sly genes. Five different virulence-associated gene profiles (genotypes) were obtained from 40 S. suis isolates (Table 2). It was found that the $m r p+/$ epf-/sly-genotype (18 of $40,45 \%$ ) was the predominant genotype among the pig isolates tested. This is consistent with previous research [2]. This genotype comprises strains of serotype 3 , three probably unencapsulated typable strains (serotypes 17, 21 and 22) identified by multiplex PCR as found by Okura et al. [16] and nine of the remaining nontypable strains. No variant phenotype of mrp was found in the isolates, whereas the epf variant (epf*) was detected in one isolate of serotype 4 . All serotype 2 isolates presented the same genotype, mrp-/epf-/sly+, in contrast to strains isolated from humans in the same geographical region that carried the mrp+lepf-/sly- genotype (80.6\%) [22]. These results indicate a difference within serotype 2; strains from humans presented only the mrp gene, while strains from pigs presented only the sly gene. While this present research was conducted using strains from pig carcasses, serotype 2 isolated from diseased pigs in China was found to have the $m r p+/$ epf $+/$ sly + genotype [24]. Unfortunately, no data on the serotype and genotype of $S$. suis from diseased pigs in Thailand are available, which makes comparisons impossible. Studies with additional strains as well as analysis of the strains by multilocus sequence typing will significantly contribute to the knowledge about serotype 2 pig and human strains isolated in this part of the country. The mrp-lepf-/ sly-genotype was distributed in many serotypes, including serotypes 3, 4, 5, 9 and 31 . This genotype is the most prevalent in the isolates from Chinese slaughtered pigs. This could imply great genetic heterogeneity and geographical variation of $S$. suis.

In conclusion, vastly different serotypes were firstly found from $S$. suis isolates originally isolated from pig carcasses sold in wet markets in Chiang Mai, Northern Thailand. The important finding is that serotypes isolated from human patients were also present in pig carcasses, which are used in local raw pork dishes. The results of this study should have a significant positive impact on the prevention of human $S$. suis infection from the traditional habit of consuming raw pork dishes and provide essential information about the S. suis serotypes and genotypes present in pigs in Thailand.

ACKNOWLEDGMENT. The study was supported by a grant-in-aid from the Endowment Fund for Medical Research, Faculty of Medicine, Chiang Mai University, Thailand.

\section{REFERENCES}

1. Callejo, R., Prieto, M., Salamone, F., Auger, J. P., GoyetteDesjardins, G. and Gottschalk, M. 2014. Atypical Streptococcus suis in man, Argentina, 2013. Emerg. Infect. Dis. 20: 500-502. [Medline] [CrossRef]

2. Chatellier, S., Gottschalk, M., Higgins, R., Brousseau, R. and Harel, J. 1999. Relatedness of Streptococcus suis serotype 2 isolates from different geographic origins as evaluated by molecular fingerprinting and phenotyping. J. Clin. Microbiol. 37: 362-366. [Medline]

3. Fittipaldi, N., Segura, M., Grenier, D. and Gottschalk, M. 2012. Virulence factors involved in the pathogenesis of the infection caused by the swine pathogen and zoonotic agent Streptococcus suis. Future Microbiol. 7: 259-279. [Medline] [CrossRef]

4. Gottschalk, M., Segura, M. and Xu, J. 2007. Streptococcus suis 
infections in humans: the Chinese experience and the situation in North America. Anim. Health Res. Rev. 8: 29-45. [Medline] [CrossRef]

5. Gottschalk, M., Xu, J., Calzas, C. and Segura, M. 2010. Streptococcus suis: a new emerging or an old neglected zoonotic pathogen? Future Microbiol. 5: 371-391. [Medline] [CrossRef]

6. Gottschalk, M., Lacouture, S., Bonifait, L., Roy, D., Fittipaldi, N. and Grenier, D. 2013. Characterization of Streptococcus suis isolates recovered between 2008 and 2011 from diseased pigs in Québec, Canada. Vet. Microbiol. 162: 819-825. [Medline] [CrossRef]

7. Gomez, E., Kennedy, C. C., Gottschalk, M., Cunningham, S. A., Patel, R. and Virk, A. 2014. Streptococcus suis-related prosthetic joint infection and streptococcal toxic shock-like syndrome in a pig farmer in the United States. J. Clin. Microbiol. 52: 22542258. [Medline] [CrossRef]

8. Gustavsson, C. and Ramussen, M. 2014. Septic arthritis caused by Streptococcus suis serotype 5 in pig farmer. Emerg. Infect. Dis. 20: 489-490. [Medline] [CrossRef]

9. Ip, M., Fung, K. S., Chi, F., Cheuk, E. S., Chau, S. S., Wong, B. W., Lui, S., Hui, M., Lai, R. W. M. and Chan, P. K. S. 2007. Streptococcus suis in Hong Kong. Diagn. Microbiol. Infect. Dis. 57: 15-20. [Medline] [CrossRef]

10. Kerdsin, A., Akeda, Y., Hatrongjit, R., Detchawna, U., Sekizaki, T., Hamada, S., Gottschalk, M. and Oishi, K. 2014. Streptococcus suis serotyping by a new multiplex PCR. J. Med. Microbiol. 63: 824-830. [Medline] [CrossRef]

11. Kerdsin, A., Dejsirilert, S., Puangpatra, P., Sripakdee, S., Chumla, K., Boonkerd, N., Polwichai, P., Tanimura, S., Takeuchi, D., Nakayama, T., Nakamura, S., Akeda, Y., Gottschalk, M., Sawanpanyalert, P. and Oishi, K. 2011. Genotypic profile of Streptococcus suis serotype 2 and clinical features of infection in humans, Thailand. Emerg. Infect. Dis. 17: 835-842. [Medline] [CrossRef]

12. Kerdsin, A., Dejsirilert, S., Sawanpanyalert, P., Boonnark, A., Noithachang, W., Sriyakum, D., Simkum, S., Chokngam, S., Gottschalk, M., Akeda, Y. and Oishi, K. 2011. Sepsis and spontaneous bacterial peritonitis in Thailand. Lancet 378: 960. [Medline] [CrossRef]

13. Kerdsin, A., Oishi, K., Sripakdee, S., Boonkerd, N., Polwichai, P., Nakamura, S., Uchida, R., Sawanpanyalert, P. and Dejsirilert, S. 2009. Clonal dissemination of human isolates of Streptococcus suis serotype 14 in Thailand. J. Med. Microbiol. 58: 1508-1513. [Medline] [CrossRef]

14. Maneerat, K., Yongkiettrakul, S., Kramomtong, I., Tongtawe, P., Tapchaisri, P., Luangsuk, P., Chaicumpa, W., Gottschalk, M. and Srimanote, P. 2013. Virulence genes and genetic diversity of Streptococcus suis serotype 2 isolates from Thailand. Transbound. Emerg. Dis. 60 Suppl 2: 69-79. [Medline] [CrossRef]

15. Nghia, H. D. T., Hoa, N. T., Linh, D., Campbell, J., Diep, T. S., Chau, N. V. V., Mai, N. T. H., Hien, T. T., Spratt, B., Farrar, J. and Schultsz, C. 2008. Human case of Streptococcus suis serotype 16 infection. Emerg. Infect. Dis. 14: 155-157. [Medline] [CrossRef]

16. Okura, M., Lachance, C., Osaki, M., Sekizaki, T., Maruyama, F., Nozawa, T., Nakagawa, I., Hamada, S., Rossignol, C., Gottschalk, M. and Takamatsu, D. 2014. Development of a two-step multiplex PCR assay for typing of capsular polysaccharide synthesis gene clusters of Streptococcus suis. J. Clin. Microbiol. 52: 1714-1719. [Medline] [CrossRef]

17. Okwumabua, O., Abdelmagid, O. and Chengappa, M. M. 1999. Hybridization analysis of the gene encoding a hemolysin (sui- lysin) of Streptococcus suis type 2: evidence for the absence of the gene in some isolates. FEMS Microbiol. Lett. 181: 113-121. [Medline] [CrossRef]

18. Okwumabua, O., O’Connor, M. and Shull, E. 2003. A polymerase chain reaction (PCR) assay specific for Streptococcus suis based on the gene encoding the glutamate dehydrogenase. FEMS Microbiol. Lett. 218: 79-84. [Medline] [CrossRef]

19. Schultsz, C., Jansen, E., Keijzers, W., Rothkamp, A., Duim, B., Wagenaar, J. A. and van der Ende, A. 2012. Differences in the population structure of invasive Streptococcus suis strains isolated from pigs and from humans in The Netherlands. PLoS ONE 7: e33854. [Medline] [CrossRef]

20. Silva, L. M., Baums, C. G., Rehm, T., Wisselink, H. J., Goethe, R. and Valentin-Weigand, P. 2006. Virulence-associated gene profiling of Streptococcus suis isolates by PCR. Vet. Microbiol. 115: 117-127. [Medline] [CrossRef]

21. Takeuchi, D., Kerdsin, A., Pienpringam, A., Loetthong, P., Samerchea, S., Luangsuk, P., Khamisara, K., Wongwan, N., Areeratana, P., Chiranairadul, P., Lertchayanti, S., Petcharat, S., Yowang, A., Chaiwongsaen, P., Nakayama, T., Akeda, Y., Hamada, S., Sawanpanyalert, P., Dejsirilert, S. and Oishi, K. 2012. Population-based study of Streptococcus suis infection in humans in Phayao Province in northern Thailand. PLOS ONE 7: e31265. [Medline]

22. Tharavichitkul, P., Wongsawan, K., Takenami, N., Pruksakorn, S., Fongcom, A., Gottschalk, M., Khanthawa, B., Supajatura, V. and Takai, S. 2014. Correlation between PFGE Groups and mrp/epf/sly Genotypes of Human Streptococcus suis Serotype 2 in Northern Thailand. J. Pathogens 2014: 350416. [Medline] [CrossRef]

23. Wang, K., Fan, W., Wisselink, H. and Lu, C. 2011. The cps locus of Streptococcus suis serotype 16: development of a serotypespecific PCR assay. Vet. Microbiol. 153: 403-406. [Medline] [CrossRef]

24. Wang, K., Zhang, W., Li, X., Lu, C., Chen, J., Fan, W. and Huang, B. 2013. Characterization of Streptococcus suis isolates from slaughter swine. Curr. Microbiol. 66: 344-349. [Medline] [CrossRef]

25. Wangsomboonsiri, W., Luksananun, T., Saksornchai, S., Ketwong, K. and Sungkanuparph, S. 2008. Streptococcus suis infection and risk factors for mortality. J. Infect. 57: 392-396. [Medline] [CrossRef]

26. Wei, Z., Li, R., Zhang, A., He, H., Hua, Y., Xia, J., Cai, X., Chen, H. and Jin, M. 2009. Characterization of Streptococcus suis isolates from the diseased pigs in China between 2003 and 2007. Vet. Microbiol. 137: 196-201. [Medline] [CrossRef]

27. Wertheim, H. F., Nguyen, H. N., Taylor, W., Lien, T. T., Ngo, H. T., Nguyen, T. Q., Nguyen, B. N. T., Nguyen, H. H., Nguyen, H. M., Nguyen, C. T., Dao, T. T., Nguyen, T. V., Fox, A., Farrar, J., Schultsz, C., Nguyen, H. D., Nguyen, K. V. and Horby, P. 2009. Streptococcus suis, an important cause of adult bacterial meningitis in northern Vietnam. PLoS ONE 4: e5973. [Medline] [CrossRef]

28. Wisselink, H. J., Reek, F. H., Vecht, U., Stockhofe-Zurwieden, N., Smits, M. A. and Smith, H. E. 1999. Detection of virulent strains of Streptococcus suis type 2 and highly virulent strains of Streptococcus suis type 1 in tonsillar specimens of pigs by PCR. Vet. Microbiol. 67: 143-157. [Medline] [CrossRef]

29. Zhang, C. -P., Ning, Y. -B., Zhang, Z.-Q., Song, L., Qiu, H. -S., Gao, H. -Y. and Fan, X. -Z. 2009. Prevalence of Streptococcus suis isolated from clinically healthy sows in China. Agric. Sci. China 8: 638-642. [CrossRef] 